\title{
Correction: BISMICS consensus statement: implementing a safe minimally invasive mitral programme in the UK healthcare setting
}

Vohra HA, Salmasi MY, Chien L, et al. BISMICS consensus statement: implementing a safe minimally invasive mitral programme in the UK healthcare setting. Open Heart 2020;7:e001259. doi: 10.1136/openhrt-2020-001259corr1.

Co-author Massimo Caputo was previously omitted from the author list and has now been added as the 4th author. Additionally, the following funding statement has been added since the article was first published: "The British Heart Foundation, Cardiovascular theme of NIHR Bristol Biomedical Research Centre, supported this work. The funders played no role in the design of the study, in the collection, analysis and interpretation of data, or in the decision to submit the manuscript for publication."

Open access This is an open access article distributed in accordance with the Creative Commons Attribution Non Commercial (CC BY-NC 4.0) license, which permits others to distribute, remix, adapt, build upon this work non-commercially, and license their derivative works on different terms, provided the original work is properly cited, appropriate credit is given, any changes made indicated, and the use is non-commercial. See: http://creativecommons.org/licenses/by-nc/4.0/.

(C) Author(s) (or their employer(s)) 2020. Re-use permitted under CC BY-NC. No commercial re-use. See rights and permissions. Published by BMJ.

Open Heart 2020;7:e001259corr1. doi:10.1136/openhrt-2020-001259corr1

Check for updates 